\title{
NEW RECORDS OF LEPTACANTHICHTHYS GRACILISPINIS AND MICROLOPHICHTHYS MICROLOPHUS (ACTINOPTERYGII: LOPHIIFORMES: ONEIRODIDAE) FROM THE SUBARCTIC ATLANTIC OCEAN, INCLUDING NEW LOPHIIFORM BARCODING DATA AND A RARE OBSERVATION OF A COPEPOD PARASITE IN CERATIOID ANGLERFISHES
}

\author{
Jan Y. POULSEN ${ }^{1,2^{*}}$ \\ ${ }^{1}$ Greenland Institute of Natural Resources, Nuuk, Greenland \\ ${ }^{2}$ Fish Section, Australian Museum, Sydney NSW, Australia
}

Poulsen J.Y. 2019. New records of Leptacanthichthys gracilispinis and Microlophichthys microlophus (Actinopterygii: Lophiiformes: Oneirodidae) from the subarctic Atlantic Ocean, including new lophiiform barcoding data and a rare observation of a copepod parasite in ceratioid anglerfishes. Acta Ichthyol. Piscat. 49 (4): 403-414.

\begin{abstract}
In an ongoing effort to document and/or validate taxonomic identifications and monitor fishes in the subarctic Atlantic Oceans, including the production of pragmatic identification material, two new distributional records of ceratioid anglerfishes are presented: Leptacanthichthys gracilispinis (Regan, 1925) and Microlophichthys microlophus (Regan, 1925) of the dreamer family Oneirodidae. The former belongs to the relatively rarely observed "long-pectoraled" subgroup whereas the latter is a relatively common species distributed circumglobally in temperate and tropical waters. Both species were recorded for the first time off Greenland and the specimens could be expatriates although the diversity of deep-sea pelagic fishes in the subarctic Atlantic Ocean is not well known. In addition, molecular barcoding Coxl DNA sequences of subarctic Atlantic lophiiform taxa are included, where the material was available, many being produced as part of the Greenland fishes barcoding program, a continuous effort to register and barcode all Greenland fish species. The program has currently barcoded 220 taxa of approximately 300 known fish species observed in Greenland waters, with the ceratioid anglerfishes constituting one of the most problematic fish groups in the region in terms of sampling, identification, and taxonomic assignments using integrative taxonomy. Taxonomic issues based on molecular OTUs** are reported for the genera Caulophryne, Cryptopsaras, and Dolopichthys based on Coxl data. Finally, a relatively large copepod parasite in the family Pennellidae was found on L. gracilispinis and constitutes one of only two copepod parasites recorded on ceratioid anglerfishes.
\end{abstract}

Keywords: Ceratioidei, Greenland fishes, Monitoring of subarctic fishes, diversity, Cox 1

\section{INTRODUCTION}

Anglerfishes of the suborder Ceratioidei are the deepsea component of the order Lophiiformes, otherwise associated with mostly shallow-water benthic frog- and toadfishes (Pietsch and Orr 2007, Miya et al. 2010). Ceratioids exhibit extraordinary adaptations to the deepsea pelagic habitats. All females of the 169 ceratioid species (Bañón et al. 2019), with the exception of two species in the family Caulophrynidae and the monotypic Neoceratias spinifer Pappenheim, 1914, are mimetic aggressive anglers showing a modified first dorsal fin that have evolved into a long shaft (the illicium) with a distal bioluminescent bulb (the esca) (Lütken 1871, Bertelsen 1951, Pietsch 2009). The esca of metamorphosed females contains bioluminescent-producing bacteria (Hansen and
Herring 1977, Munk et al. 1998) that have co-evolved with the host ceratioid species (Haygood et al. 1992). As a consequence, the co-evolving bacteria possess reduced genomes as compared to free-living relatives (Hendry et al. 2018). Both illicium and esca vary between the majority of species and therefore are important taxonomic characters (Parr 1927) and represent the basic knowledge needed to comprehend communication biology of these fishes. Bioluminescence in ceratioids is not fully understood although it is believed to function at least in attracting prey as well as in reproductive signalling (Pietsch 2009). However, as males are usually levels of magnitudes smaller than the females, and possess large olfactory organs, pheromones working within close range could be as important as the light for the latter function.

\footnotetext{
Correspondence: Dr Jan Yde Poulsen, Pinngortitaleriffik, Postbox 570, 3900 Nuuk, Greenland, phone: (299) 36 12 00, fax: (299) 36 12 12, e-mail: janydepoulsen@deepseafish.eu.

"Operational taxonomic unit.
} 
The extraordinary sexual reproductive system in ceratioids varies between deep-sea anglerfish lineages;

- Males never attach to females,

- Males attach temporarily,

- Males are facultative or obligate "parasites".

When "parasitism" is noted, a fusion of the two sexes is taking place and the male is attached for life and nourished by the female (Pietsch 1976, 2005, Pietsch and Orr 2007). Males showing temporary attachment (or pre-fusion if facultative "parasites") have a "denticular apparatus" suitable for attachment and feeding (Bertelsen 1951).

Ceratioid anglerfishes in the subarctic North Atlantic are, in general, rare occurrences with the majority of species registered and known only from a single or a few stray specimens (Jónsson and Pálsson 1999, 2013, Møller et al. 2010). Many more ceratioid species have been observed south of the Sub Polar Front (SPF), e.g., in the western central Atlantic (Pietsch 2002). The SFP is an important topographic and oceanographic species barrier between the temperate and subarctic North Atlantic (Sutton et al. 2013) although depth dependent (Vecchione et al. 2015). In fact, Sutton et al. (2017) defined the subarctic western Atlantic as a distinct mesopelagic eco-region that holds primarily cold-water biodiversity assemblages. New records of anglerfishes, and other mid-water taxa could, therefore, provide important information on distributional shifts although the rarity of ceratioids and insufficient knowledge of their true distributions at present makes any trends difficult to detect.

This study describes new records of Leptacanthichthys gracilispinis (Regan, 1925) and Microlophichthys microlophus (Regan, 1925) from the subarctic Atlantic, including a description of their morphologies. Barcoding Cox 1 molecular data is included for all available subarctic oneirodid taxa with many newly constructed as part of the Greenland fishes barcoding program (Poulsen et al. 2018). Barcoding data indicate taxonomic issues in some ceratioid genera. In addition, a large crustacean parasite, rarely observed in ceratioid anglerfishes, is reported herewith. The new records and molecular data presented are part of a larger continuous taxonomic and monitoring effort off Greenland, a region that has witnessed many new species distributions the last 10 years, with the caveat that deep-sea pelagic waters are poorly known and difficult to monitor.

\section{MATERIALS, METHODS}

Material. One specimen of Leptacanthichthys gracilispinis was caught by $R / V$ Pâmiut, Greenland Institute of Natural Resources (GINR), leg 6, haul 33, 23 September 2009, in the Davis Strait off south-western Greenland at $64.04^{\circ} \mathrm{N}, 057.37^{\circ} \mathrm{W}$. It was deposited at the Zoological Museum University of Copenhagen (ZMUC) as ZMUC P922698 (tissue/field JYP\#8126). Coll./ID J.Y. Poulsen. The bottom and fishing depth was within $942-950 \mathrm{~m}$, with a bottom temperature of $3.74^{\circ} \mathrm{C}$, although the actual catch depth is uncertain due to non-closing trawls. The specimen was barcoded (GLF140) as part of the Greenland Fishes (GLF) barcoding project (Poulsen et al. 2018) at BOLD* (Ratnasingham and Hebert 2007).

One specimen of Microlophichthys microlophus was caught also by $R / V$ Pâmiut, leg 4, haul 14, 24 July 2017, on the Irminger Sea slopes off south-eastern Greenland at $61.57^{\circ} \mathrm{N}, 40.16^{\circ} \mathrm{W}$. It was deposited as ZMUC P922698 (tissue/field JYP\#1862). Coll./ID J.Y. Poulsen. The bottom and fishing depth was within 1454-1465 $\mathrm{m}$ and the bottom temperature was $3.45^{\circ} \mathrm{C}$. This specimen was also caught during a routine survey with a non-closing Alfredo III trawl probing Greenland halibut abundances and the real catch depth uncertain. Barcode GLF319.

The specimens were X-rayed at the Australian Museum (AMS) and ZMUC and examined under stereomicroscopes. The morphological measurements were taken using a digital calliper to the nearest $0.1 \mathrm{~mm}$ and compared to all previous specimens recorded by Pietsch (1976, 1978, 2009) (Table 1).

The copepod parasite attached to L. gracilispinis (Fig. 1B) was photo-identified as a taxon within the Pennellidae family, possibly Sarcotretes scopeli Jungersen, 1911 by Geoffrey A. Boxshall at the British Museum of Natural History (BMNH).

\section{RESULTS}

Oneirodidae Gill, 1878

Leptacanthichthys Regan et Trewavas, 1932

Leptacanthichthys gracilispinis (Regan, 1925)

(Table 1, Fig. 1A-E)

Description. (Based on specimen ZMUC P922698): First radial shorter than second and pectoral-fin lobe long, narrow, longer than longest fin ray (dorsally positioned); short and broad suboperculum; pharyngobranchials II and III showing 8 long slender teeth; frontals relatively straight; sphenotic spines large, appearing vertical when viewed from anterior, with posterior slant when viewed from side; lower jaw broken at symphysis although small symphysial spine present ventrally, larger knob present dorsally; maxillomandibular ligament 9.8 $\mathrm{mm}(15.8 \% \mathrm{SL})$; posterior part of lower jaw showing "Leptacanthichthys" configuration: long mandibular spine present, shorter quadrate spine and angular bone without distinct spine (Fig. 1); bases of mandibular and quadrate spines broken off left and right sides, however, spines still present although rotated compared to their correct positions; multiple teeth in lower jaw, highly variable in size, some fang-like and almost straight; fewer upper jaw teeth, much smaller, less variable in size, fang-like teeth absent; vertebral column strong and ossified; large neural spines present, anterior four particularly large; haemal spines present, anterior two large; pre-caudal vertebrae 3; caudal vertebrae 17; ribs, epipleurals and epineurals absent (Fig. 1C); caudal fin rays 9: 2 simple +4 bifurcated +3 simple; pterygiophore of illicium $3.2 \mathrm{~mm}$ (5.2\% SL), wider than illicium, originating between anterior part of frontals; illicium slender, especially at midpoint, and flexible; esca with pigmented streak on dorsal margin 
and single posterior compressed appendage containing no bioluminescent dark tissue (Fig. 1D). Reproductive state: Ovaries $6 \mathrm{~mm}$ in lengths, flaccid, suggesting spent or previous larger eggs present now gone; minute eggs present, largest $0.1 \mathrm{~mm}$ diameter in ovary walls along its entire length.

\section{Microlophichthys Regan et Trewavas, 1932 Microlophichthys microlophus (Regan, 1925)} (Table 1, Fig. 2A-E)

Description. (Based on specimen ZMUC P2395464): Sphenotic spines present, large symphysial spine present ventrally, no discernible spine dorsally on lower jaws; quadrate spine robust; opercle notched posteriorly; pectoral fin lobe large, approximately equal in length to fin rays or slightly shorter, that are situated somewhat dorsoposterior on lobe; dorsal fin in advance of anal-fin origin; teeth on lower jaws variable in size on whole jaw; teeth on premaxillaries in multiple rows, variable in size only in the anterior parts; skin smooth, although most skin lost on specimen; subopercle distally expanded and rounded; esca with appendage without bioluminescent tissue, red bulb under bioluminescent tissue in esca (Fig. 2D); stomach content white mass, items indiscernible. Morphological characters similar to those described by
Pietsch (2009) and not included for further descriptions (Table 1). Reproductive state: Ovaries $6.2 \mathrm{~mm}$ in lengths, red coloured, no eggs visible.

Cox1 DNA barcoding sequences. In order to support a more comprehensive comparison of Coxl barcodes of ceratioids in general, I included here all subarctic Atlantic taxa that have barcoding data available. Ceratioid observations in the subarctic regions are based on the presently reported study, Pietsch (2009), Møller et al. (2010), Jónsson and Pálsson (2013), and the Global Biodiversity Information Facility (Anonymous 2012). All specimens included for the Coxl barcode in this study are metamorphosed females. A Kimura-2Parameter (K2P) (Kimura 1980) model was employed for the analysis of the dataset consisting of 55 specimens including a total of 22 subarctic Atlantic distributed taxa (Table 2). The resulting topology is shown in Fig. 3. Three taxonomic results based on Coxl barcodes related to the genera Dolopichthys, Cryptopsaras, and Caulophryne are discussed below. Besides that, the Coxl barcoding results are not discussed further due to the inclusion of only subarctic Atlantic taxa and the focus on molecular taxonomy of ceratioids in the subarctic Atlantic.

The copepod parasite attached to L. gracilispinis (Fig. 1B) was photo-identified as a taxon, within the family

Table 1

Morphometric and meristic data of Leptacanthichthys gracilispinis and Microlophichthys microlophus, caught off south-western and south-eastern Greenland respectively during the presently reported study (ZMUC specimens), compared to specimens examined by Pietsch (2009)

\begin{tabular}{|c|c|c|c|c|c|c|c|c|c|c|}
\hline \multirow{2}{*}{$\begin{array}{c}\text { Parameters } \\
\text { Specification }\end{array}$} & \multicolumn{6}{|c|}{ Leptacanthichthys gracilispinis } & \multicolumn{4}{|c|}{ Microlophichthys microlophus } \\
\hline & \multicolumn{3}{|c|}{ ZMUC P922698 } & \multicolumn{3}{|c|}{ Pietsch (2009) 24 specimens } & ZMUC P2395464 & \multicolumn{3}{|c|}{ Pietsch (2009) 94 specimens } \\
\hline \multirow[t]{2}{*}{ Distribution } & \multicolumn{3}{|c|}{$64.04^{\circ} \mathrm{N}, 057.37^{\circ} \mathrm{W}$} & \multicolumn{3}{|c|}{ Circumglobal } & $61.57^{\circ} \mathrm{N}, 040.16^{\circ} \mathrm{W}$ & \multicolumn{3}{|c|}{ Circumglobal } \\
\hline & {$[\mathrm{mm}]$} & {$[\% \mathrm{SL}]$} & Count & {$[\mathrm{mm}]$} & {$[\% \mathrm{SL}]$} & Count & {$[\mathrm{mm}]$} & {$[\mathrm{mm}]$} & {$[\% \mathrm{SL}]$} & Count \\
\hline $\mathrm{SL}[\mathrm{mm}]$ & 62.1 & & & $22.0-56.0$ & & & 112.7 & $11.5-112$ & & \\
\hline Head & & 38.5 & & & $29.1-33.3$ & & 43.7 & & $31.1-39.2$ & \\
\hline Lower jaw & & 27.4 & & & $26.7-34.1$ & & 29.2 & & $34.9-46.8$ & \\
\hline Premaxillary & & 23.3 & & & $22.0-24.6$ & & 23.3 & & $28.8-31.9$ & \\
\hline Illicium & & 20.0 & & & $19.2-24.1$ & & 9.7 & & $8.3-10.3$ & \\
\hline Pectoral lobe & & 7.7 & & & $7.7-10.0$ & & & & & \\
\hline Sphenotic spine & & 4.3 & & & $3.6-4.9$ & & & & & \\
\hline Quadrate spine & & 4.8 & & & $2.8-4.5$ & & & & & \\
\hline Mandibular spine & & 6.9 & & & $4.6-6.8$ & & & & & \\
\hline Head depth & & 28.5 & & & $30.9-34.9$ & & 39.0 & & $35.8-43.2$ & \\
\hline Dorsals & & & 5 & & & $4-6(5)$ & 7 & & & $5-7$ \\
\hline Anals & & & 5 & & & $5-6(5)$ & 5 & & & $4-6(5)$ \\
\hline Pectorals & & & 20 & & & $18-21(21)$ & 14 & & & $17-20$ \\
\hline Caudals & & & 9 & & & & 9 & & & 9 \\
\hline Vertebrae $^{\mathrm{U}}$ & & & 22 & & & & 22 & & & \\
\hline Dentition Vomer & & & $5+5$ & & & $3+3-6+6$ & $5+5$ & & & $4-12$ \\
\hline Dentition Upper jaw & & & 40 & & & $52-154$ & $180^{\mathrm{U}}$ & & & $160-320$ \\
\hline Dentition Lower jaw & & & 70 & & & $44-106$ & $100^{\mathrm{T}}$ & & & $100-180$ \\
\hline
\end{tabular}

ZMUC = Zoological Museum University of Copenhagen; SL = standard length of fish; numbers in parentheses are the most common meristic counts for the particular characters; ${ }^{U}$ vertebral counts include the posterior urostyle and the most anterior "half-vertebra" connecting the vertebral column to the cranium, ${ }^{\mathrm{T}} \mathrm{j}$ aw teeth counts are approximate as numerous small teeth are present. 
Pennellidae, possibly Sarcotretes scopeli Jungersen, 1911 illicium and esca show similar morphology to what has by Geoffrey A. Boxshall at the British Museum of Natural been reported for other specimens of L. gracilispinis: the History (BMNH).

\section{DISCUSSION}

A few morphometric characters of the new subarctic record ZMUC P922698 (Leptacanthichthys gracilispinis) show values outside previously reported, such as the mandibular- and quadrate spine lengths (Table 1). However, morphometric values are generally close to the ranges noted by Pietsch (1978). Similarly, the distinct illicium is very thin compared to other ceratioids and the esca have only one large appendage without bioluminescent tissue (Fig. 1E). A peculiar feature of L. gracilispinis is the long pectoral fin lobe showing the fin rays on the dorsal margin (Fig. 1E). This is a unique configuration of the pectoral fins and is only found in a small fourgenera subgroup of dreamers in the family Oneirodidae (see Pietsch 1978): L. gracilispinis; Puck pinnata Pietsch, 1978; Ctenochirichthys longimanus Regan et Trewavas,

A
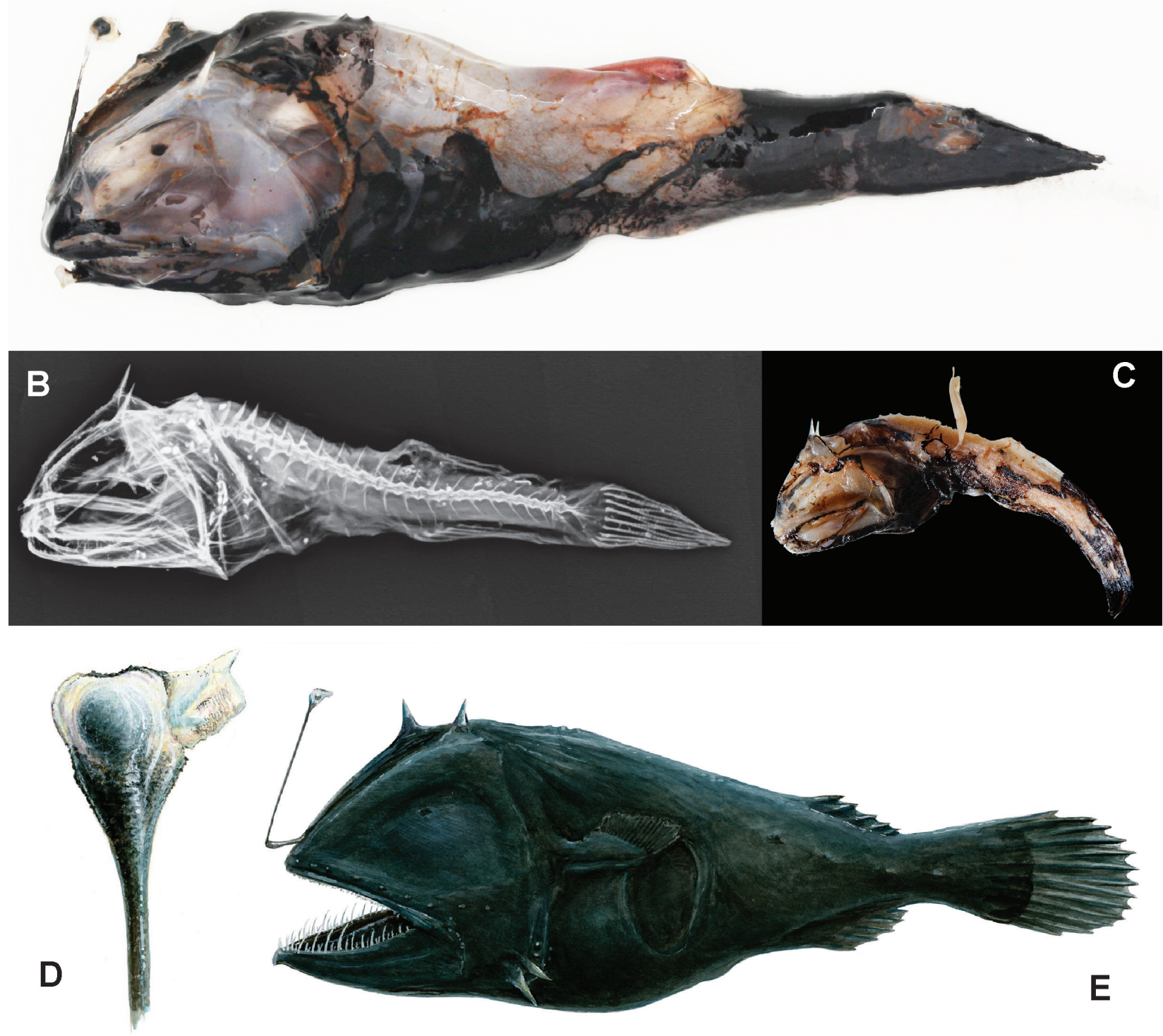

Fig. 1. Leptacanthichthys gracilispinis ZMUC P922698: (A) newly caught off south-western Greenland 2009; (B) digital radiograph image; (C) alcohol preserved; note the large mandibular (almost vertical) and quadrate (horizontal) spines designating Leptacanthichthys although base broken and both spines are rotated compared to their natural positions; a large copepod parasite can be seen on the freshly caught and the alcohol preserved specimen; (D) illustration of esca (Redrawn based on the Greenland specimen and based on R. Nielsen in Pietsch 2009); (E) illustration of the specimen; note the slender illicium on the specimen and the dark streak on the dorsal margin including a large flattened appendage containing no bioluminescent tissue on the esca 
ฮี

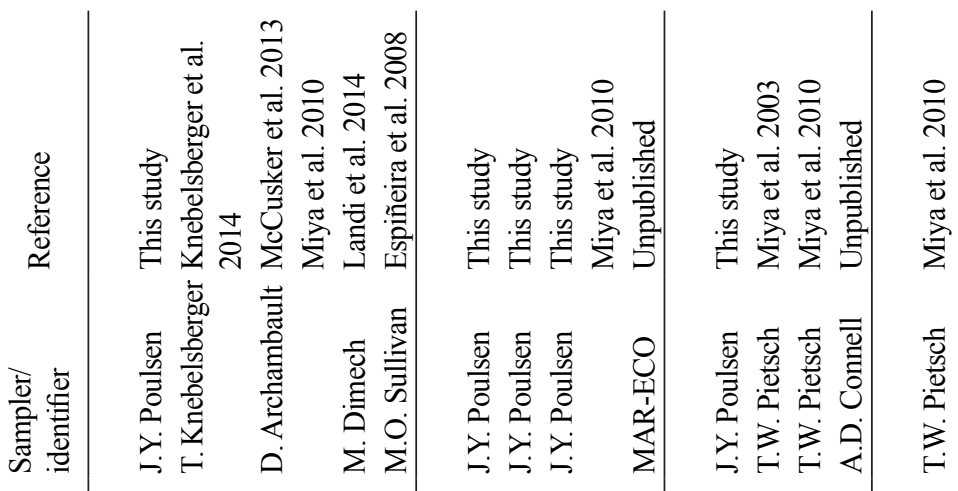

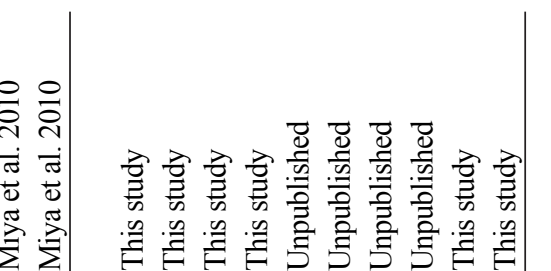

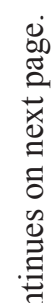

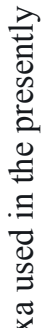

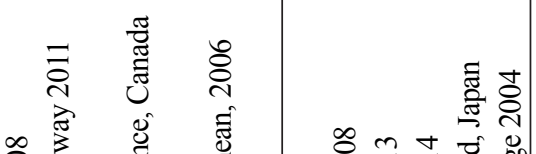

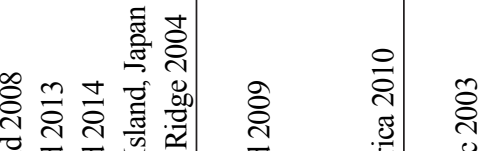

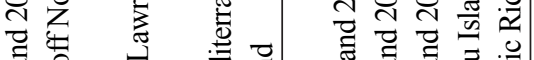

离

i

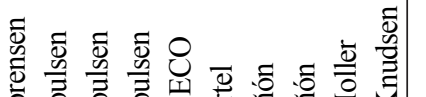

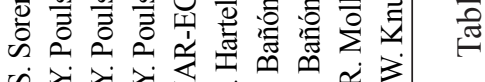

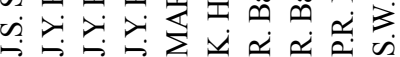

\&

究基

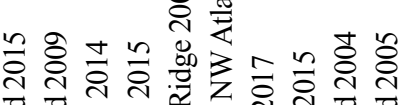

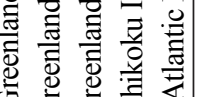

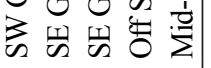

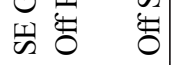

善管

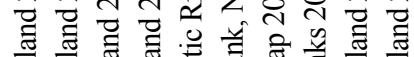

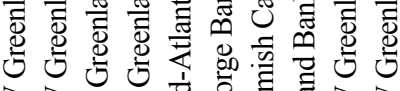

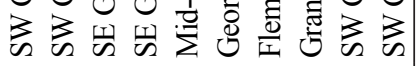

흄

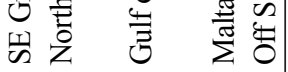

鏟哭

में ले

용

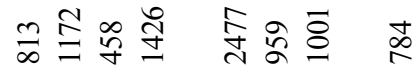

3 때

33

3

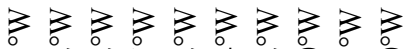

+

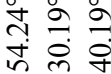

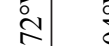

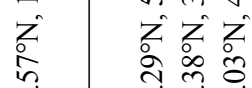

iो

i.

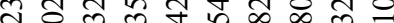

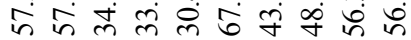

ż

วై

ż

$\begin{array}{ll}z & z \\ \text { ing } & 0 \\ 0 & 0\end{array}$

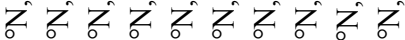

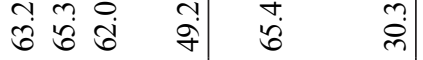

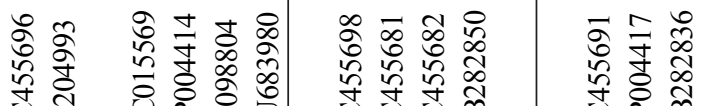

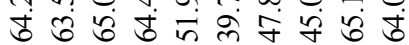

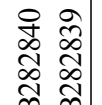

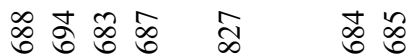

$\overrightarrow{0}$

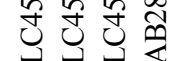

过安密

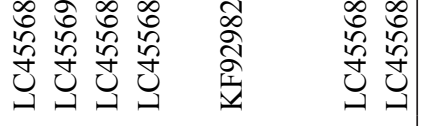

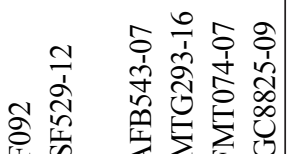

$\div$ 임

$\div \frac{0}{1} \circ$

$\begin{array}{lll}4 & 4 \\ 0 & 0 \\ 1 & 0\end{array}$

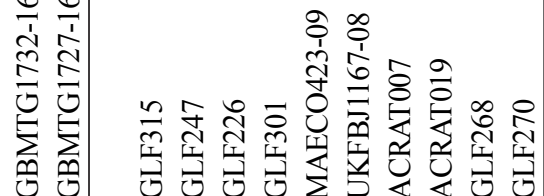

돈

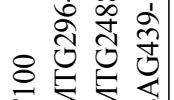

음

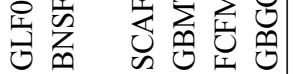

ลे \&

否兽总泀

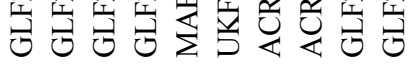

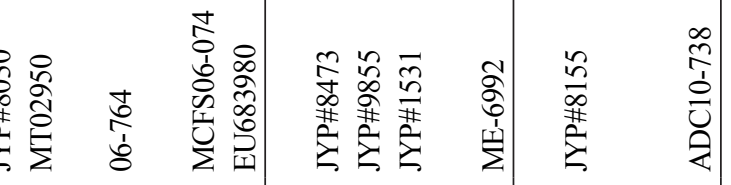

式



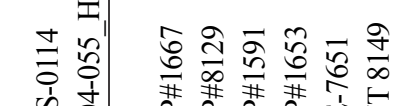

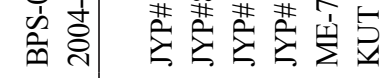

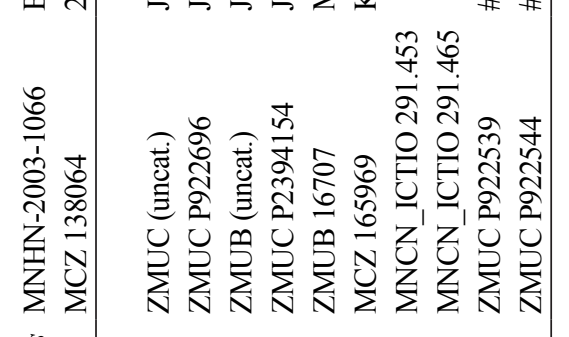

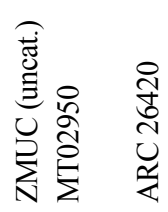

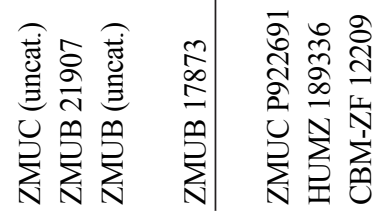

ริ

ถู

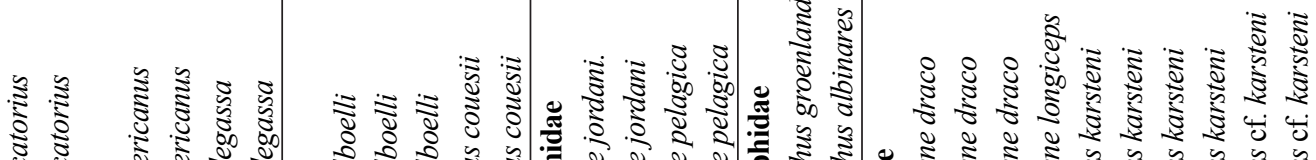

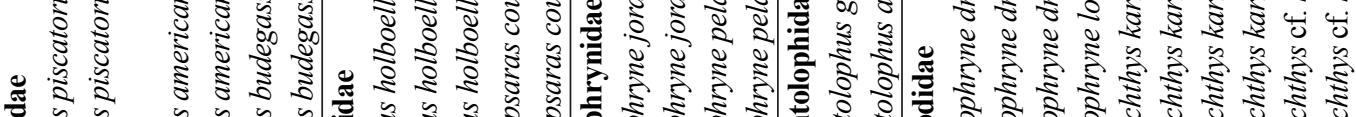

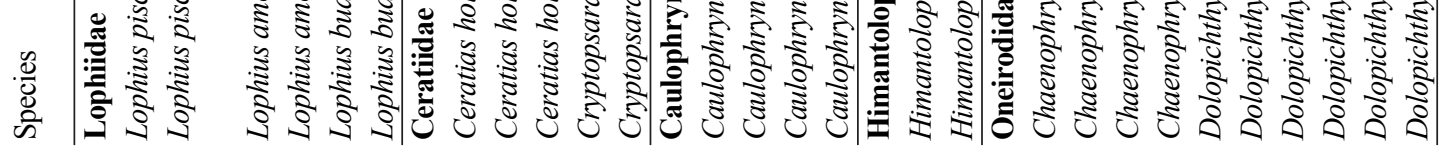




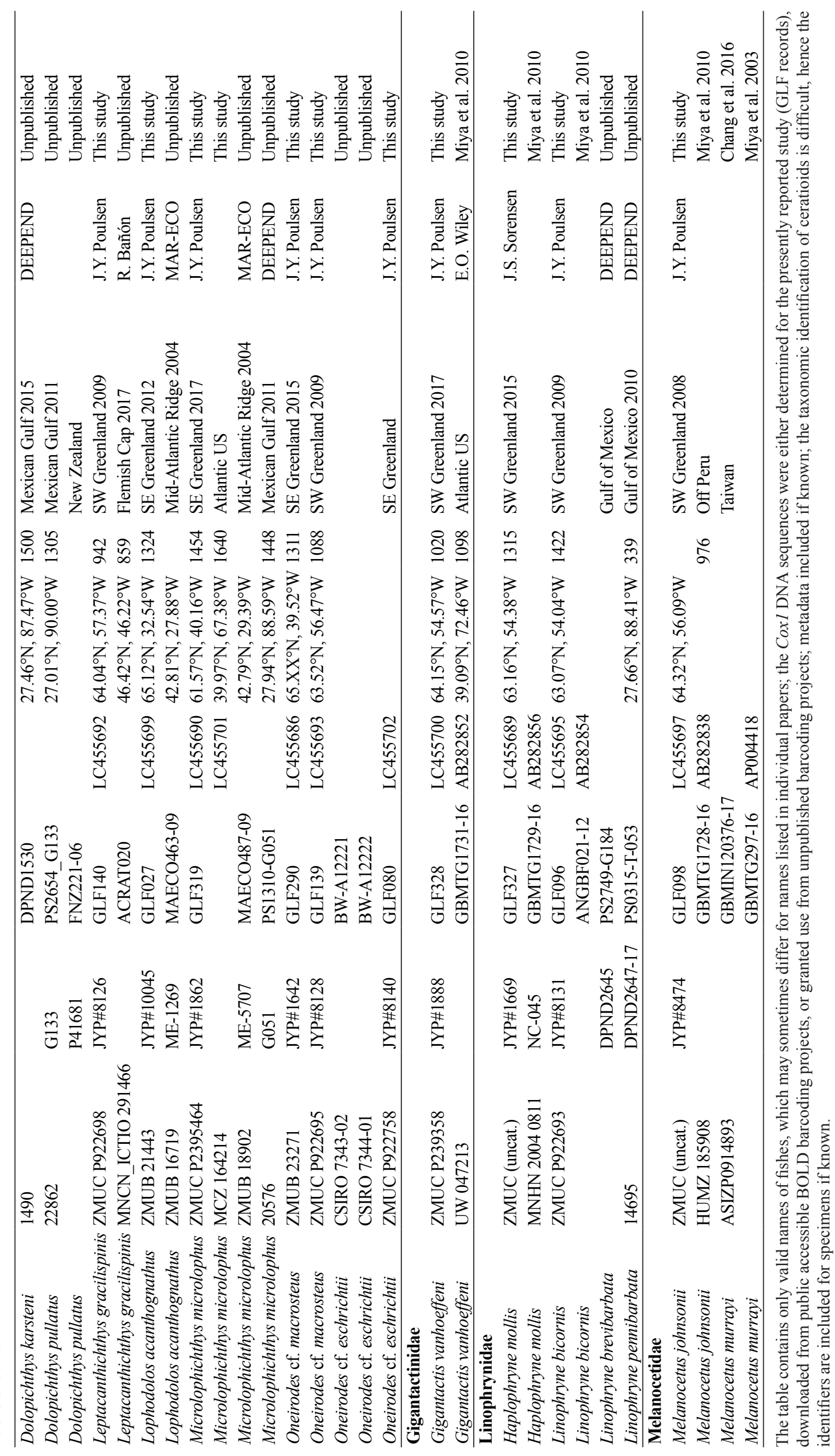


1932; and Chirophryne xenolophus Regan et Trewavas, 1932. The specimen observed off Greenland shows 100\% Cox 1 DNA sequence similarity to a specimen from the Flemish Cap (table 2 and fig. 3 of Bañón et al. 2019). The L. gracilispinis shows an uncorrected DNA sequence distance of $97 \%$ to several species within the Oneirodidae (data not shown), supporting a close association of longpectoraled dreamers within this family as already noted from morphology (Pietsch 1974, 1978, Pietsch and Orr 2007) and mitogenomic data (Miya et al. 2010). A currently unresolved phylogenetic relation of the longpectoraled genus Puck to Thaumatichthys as found by Miya et al. (2010) needs verification with additional taxa. The latter study also found multiple non-coding regions in the mitogenomes of oneirodids - characters proved very useful in elucidating phylogenetic relation (Poulsen et al. 2013). New unpublished mitogenomic data (J.Y. Poulsen data, data not shown) confirms this feature in some oneirodids.

The new subarctic record of Microlophichthys microlophus off south-eastern Greenland shows most characters within the ranges noted by Pietsch (2009) and are therefore not given much discussion. However, head length and measurements of the jaws fall outside the ranges noted in Pietsch (2009; table 1, fig. 2). The Greenland specimen is relatively large compared to previous observations (Table 1) and the small differences could be due to allometric growth changes. The Cox 1 barcode shows the Greenland specimen to have 100\% DNA sequence similarity to specimens from the Mid-

\section{A}
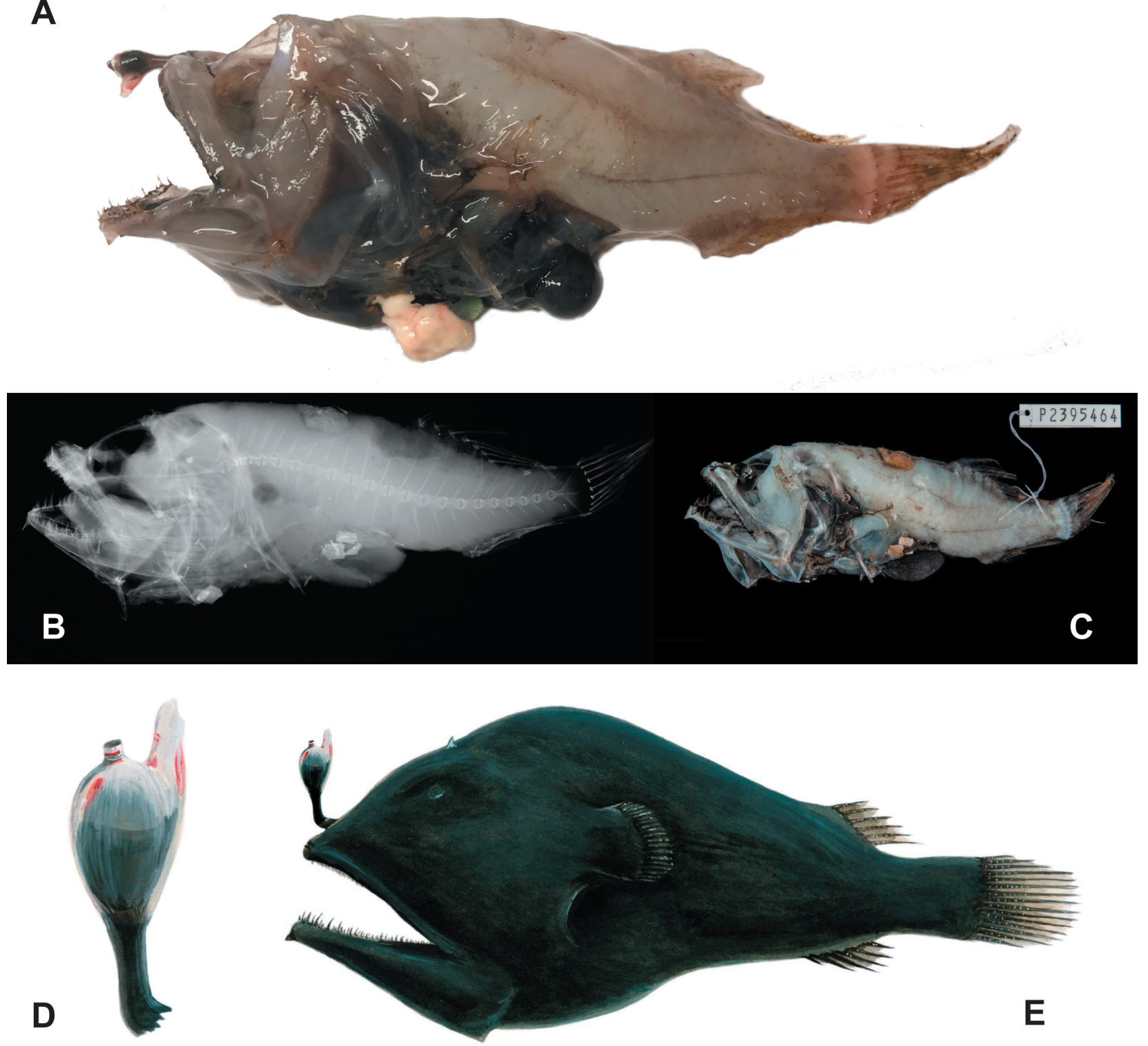

Fig. 2. Microlophichthys microlophus ZMUC P922698: (A) newly caught off south-eastern Greenland 2017; (B) digital radiograph image; (C) alcohol preserved; (D) illustration of esca; redrawn based on the Greenland specimen and based on Bertelsen (1951; cited by Pietsch 2009); (E) illustration of the specimen; note the short illicium and many minute teeth in the jaws 


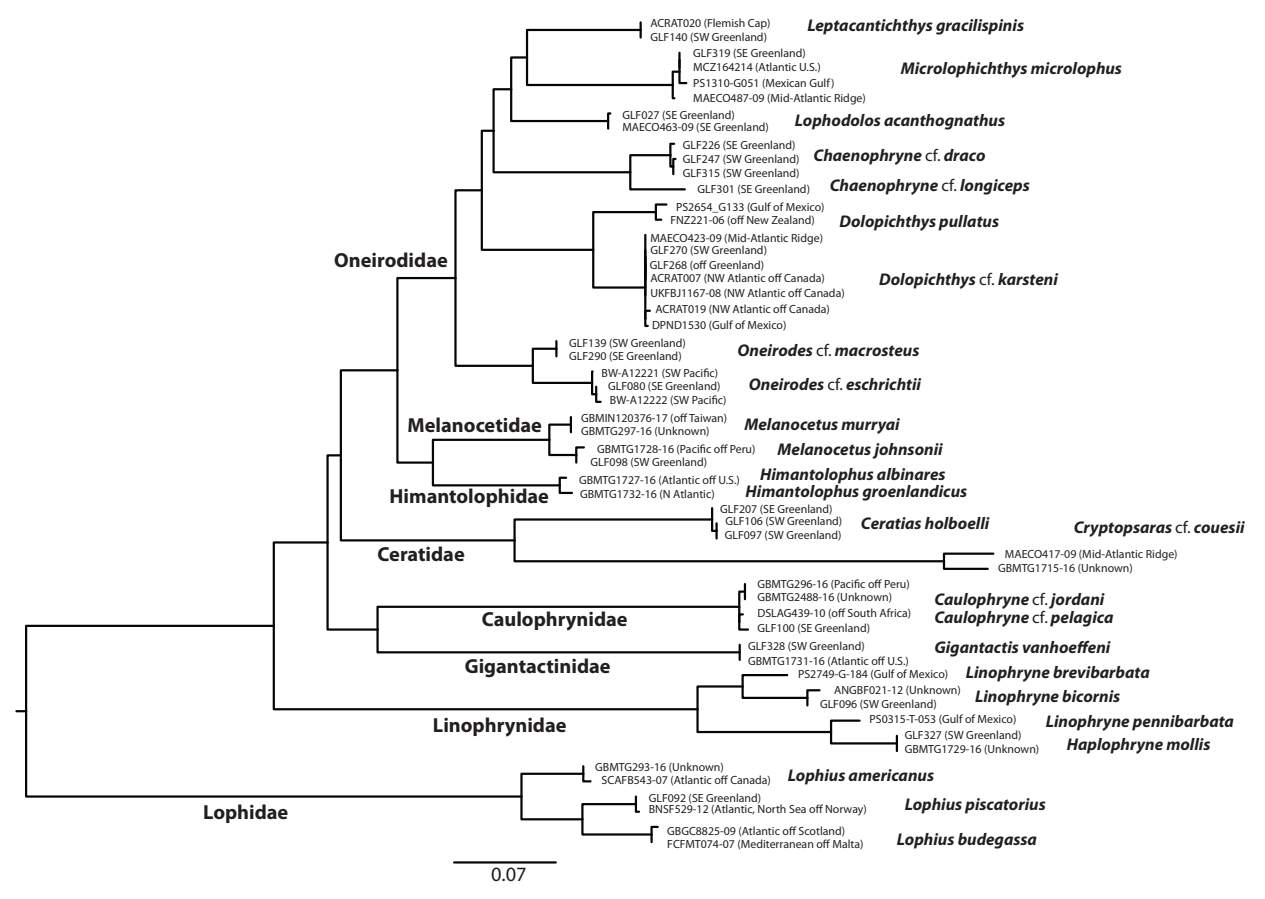

Fig. 3. K2P topology of subarctic Atlantic ceratioids based on the Coxl barcoding DNA sequences; three species of Lophius were employed as the operational outgroup; all subarctic Atlantic species in the suborder Ceratioidei with barcoding data available are included (many produced as part of the Greenland fishes barcoding program; Poulsen et al. 2018); note the one OTU in Dolopichthys karsteni and Caulophryne contrary to two OTUs in Cryptopsaras cf. couesii

Atlantic Ridge. My personal observations combined with barcoding data produced as part of the Greenland fishes barcoding project (Poulsen et al. 2018), has shown that oneirodid identification (and hence onboard sampling of specimens) off Greenland problematic for an extensive period of time. The two new records presented in this study are possible examples of such past sampling and identification errors, and the word expatriate is trivial at best at the moment.

The new L. gracilispinis specimen off Greenland provides one of approximately 35 female specimens recorded, from both the Atlantic and Pacific (Anonymous 2012), and extends the distribution into the western subarctic Atlantic at $64^{\circ} \mathrm{N}$ close to the Arctic Circle. The most northern Atlantic record previously observed was caught during pelagic trawling during the MARECO cruises in 2004 at $52.89^{\circ} \mathrm{N}, 030.59^{\circ} \mathrm{W}$ (ZMUB 16711) that also showed several more records from approximately $50^{\circ} \mathrm{N}$ (I. Byrkjedal, MAR-ECO data). Previously, $R / V$ Walter Herwig fishing in 1982 at similar latitudes as the MAR-ECO cruises, has a record at $48.90^{\circ} \mathrm{N}, 027.48^{\circ} \mathrm{W}$ (ISH 619) measuring $60 \mathrm{~mm}$ (R. Thiel data). Expatriate specimens are often showing large body size (Poulsen 2015a), and even though the Greenland specimen is $62 \mathrm{~mm}$ SL and therefore relatively large compared to presently described material, L. gracilispinis can apparently grow to $103 \mathrm{~mm}$ SL (Pietsch 2009). However, a status as expatriate of L. gracilispinis in the subarctic Atlantic is by no means substantiated, as the pelagic deep-sea realm in this region is poorly known due to a variety of factors
(Bertelsen and Krefft 1965, Poulsen 2015b, Poulsen et al. 2018). The four long-pectoraled taxa show circumglobal distributions, although not observed in the Indian Ocean as yet (Pietsch 2009). Leptacanthichthys gracilispinis is the most commonly observed of the four long-pectoral anglerfishes and indications are that it is widely distributed in the North Atlantic. The new record of M. microlophus off Greenland is unsurprising as it is relatively common in all major oceans and the temperate Atlantic (Pietsch 2009).

Greenland waters are considered too cold for ceratioid reproduction, based on comprehensive data by Bertelsen (1951) and Pietsch (2009). However, several ceratioid species are regularly observed off south-western and south-eastern Greenland (J.Y. Poulsen, personal observation): Ceratias holboelli Krøyer, 1845; Oneirodes eschrichtii Lütken, 1871; Oneirodes macrosteus Pietsch, 1974; Chaenophryne longiceps Regan, 1925; Lophodolos acanthognathus Regan, 1925; and Melanocetus johnsonii Günther, 1864. The species Linophryne coronata Parr, 1927 appears to be more common off Iceland than Greenland (Bertelsen 1976, Bañón et al. 2006, Jónsson and Pálsson 2013), although this knowledge is based on few specimens only. The remaining 31 species registered in the subarctic waters of the North Atlantic are, on the contrary, rare occurrences, known only from one or a few stray specimens (Møller et al. 2010, Jónsson and Pálsson 2013). In fact, 2009 witnessed yet another rare ceratioid specimen off south-western Greenland, the sixth specimen of Linophryne bicornis Parr, 1927 known, 
ZMUC P922693, Coll./ID J.Y. Poulsen, presented in Møller et al. (2010) with barcode GLF096 and caught at a bottom temperature of $3.64^{\circ} \mathrm{C}$. Leptacanthichthys gracilispinis, $M$. microlophus, and L. bicornis are the only three new ceratioid records that have been observed in the region for over a decade, owing to an increased sampling and taxonomic effort onboard including integrative taxonomy. Yearly fluctuations in warm North Atlantic drift waters are potentially a factor concerning observations of ceratioids in this region (Gaemers and Poulsen 2017). The large volume pelagic deep-sea water masses off the Labrador Sea (south-western Greenland) and the Irminger Sea (south-eastern Greenland) remain poorly studied, and deep-sea pelagic fishing efforts would certainly result in many new discoveries in these regions considering that benthic distributions are continuously being extended (Poulsen et al. 2018) and new recent pelagic species discovered (Poulsen 2015b). Future fish records in these regions should elucidate the subarctic north-western ecoregion as delimited by Sutton et al. (2017). Few ceratioid species with males attached (Pietsch 2009), such as, for example, Linophryne lucifer Collett, 1886 observed in 1967 by Jónsson (1967) in the Denmark Strait off southeastern Greenland (Bertelsen 1976, 1986), have been observed north of the SPF. Free-living male ceratioids seem restricted to the tropical and subtropical zones between $40^{\circ} \mathrm{N}$ and $40^{\circ} \mathrm{S}$ (Bertelsen 1951, Pietsch 1974, 2009). No attached males or signs of previous attachment were found on the new records. The L. gracilispinis specimen caught off Greenland showed only tiny eggs present and clearly not close to reproducing at the time of capture. Contrary to the yearly observations of some ceratioid species off Greenland, these results support that reproduction is not taking place at these latitudes.

Online databases dedicated to taxonomic assignments of fish species based on barcoding DNA fragments have shown valuable in several respects concerning the distribution, morphology, taxonomy, and, as a consequence, the species diversity of fishes (Ward et al. 2009, Bañón et al. 2013, Barros-García et al. 2018). This study provides barcoding data of all ceratioid species sampled off Greenland for more than a decade and is intended to support comparisons for future discoveries. All records in the Greenland fishes barcoding project are freely available in BOLD (prefix GLF, Poulsen et al. 2018). However, the BOLD database should be used with great caution concerning Cox 1 ceratioid comparisons at present, as many species show almost identical DNA sequences indicating taxonomic identifications problematic. This is evident in, for example, the family Oneirodidae, a difficult group of fishes in which damage is often present in speciesdefining characters, and therefore difficult to identify. Future works using Coxl comparisons should provide and validate identifications and metadata associated with records used (Table 2). Although several ceratioid species recorded from the subarctic Atlantic is missing for their Coxl barcode in the presently reported study, many are rare and no tissues available, three taxonomic issues can be noted from the barcoding results in the presently reported study (Fig. 3). Thorough morphological examinations of these three genera are beyond this study.

Two specimens identified as Dolopichthys longicornis Parr, 1927, the only species in the genus noted from the subarctic Atlantic (Møller et al. 2010, Jónsson and Pálsson 2013), show identical Cox1 DNA sequences to several specimens identified as Dolopichthys karsteni Leipertz et Pietsch, 1987 that were collected from different Atlantic localities such as the Mid-Atlantic Ridge and Georges Bank (Table 2). However, Pietsch (2009) noted no presence of either species in the subarctic Atlantic. I leave these results as presented for future studies employing barcoding Coxl data and note that Dolopichthys allector Garman, 1899 from the North Atlantic Ocean was found to be closely related to D. karsteni (Fig. 3).

Cryptopsaras couesii Gill, 1883 show two relatively divergent Operational Taxonomic Units (OTUs) with an uncorrected distance of 5.4\% (Kenchington et al. 2017). A total of 37 substitutions are observed in 688 base pairs of the Coxl fragment of which only two are not observed in the third codon positions (one synonymous $\mathrm{C}-\mathrm{T}$ transition and one non-synonymous $\mathrm{A}-\mathrm{G}$ transition in first codon positions). Seven of the 37 substitutions are transversions and three are non-synonymous. This variation between $C$. couesii specimens is reminiscent of substitutional variations observed in mid-water and deep-sea taxa delimited also from solid morphological characters (Byrkjedal et al. 2011, Poulsen et al. 2016). Unfortunately, no Cox 1 barcode of a $C$. couesii specimen off Greenland could be included, as this species has not been observed for more than a decade in the region, contrary to Ceratias holboelli Krøyer, 1845 that is caught annually (J.Y. Poulsen, personal observation, Fig. 3).

Caulophryne jordani Goode et Bean, 1996 and Caulophryne pelagica (Brauer, 1902) show highly similar DNA sequences, based on four specimens barcoded from the Atlantic and Pacific Oceans (Table 2). There is no structure in the few substitutions present indicating one OTU (Fig. 3). The few differences observed are mostly associated with fragment end-regions that could be caused by primer attachment artefacts in the replication process during the PCR amplification and sequencing. These primer attachment sites (usually about 20 base pairs in the end regions) are unfortunately not always removed before the Cox1 DNA sequences are uploaded to the BOLD repository (J.Y. Poulsen, personal observation). This is an issue when comparing Coxl barcodes if not assessing the locations of the variations observed. Regardless, and in respect to other ceratioid OTUs (Fig. 3 ), the variation between $C$. jordani and C. pelagica is not supporting two distinct OTUs (see Miya et al. (2010) for specimen identifications).

A plethora of crustacean parasites are found in association with deep-sea fishes (Klimpel et al. 2001) although these types of modified parasites have only been observed once in ceratioid anglerfishes (Prokofiev 2014). Therefore, the copepod parasite attached to L. gracilispinis off Greenland is the second external parasite recorded in deep-sea anglerfishes (Fig. 1A, 1C) with a hydroid 
(Hydrozoa) Hydrichthys pietschi, reported on the skin of Ceratias holboelli by Martin (1975). The parasite, presently reported from L. gracilispinis, is a copepod in the family Pennellidae and likely represents the species Sarcotretes scopeli (see G.A. Boxshall, personal comment) that has also been recorded from various other mid-water fishes. Sarcotretes scopeli is a common fish ectoparasite in the North Atlantic showing a low host-specificity (Boxshall 1998). It is reminiscent of the parasite shown by Prokofiev (2014) on Chaenophryne melanorhabdus Regan et Trewavas, 1932, although no identification was provided. Copepod parasites are regularly observed in deep-sea fishes (Boxshall 1998). The observation of only few copepod parasites observed in ceratioids is noteworthy (T. Pietsch, personal comment), although demersal species are observed much more frequent to be parasitized than meso- and bathypelagic species in the Arctic (Klimpel et al. 2006). Relatively large mesoparasitic copepod parasites (families Pennellidae and Sphyriidae), featuring an internal holdfast and the majority of the body protruding outside the fish (Piasecki and Avenant-Oldewage 2008), are common observations on various fishes off subarctic Greenland, across phylogenetically independent fish lineages (J.Y. Poulsen, personal observation).

\section{ACKNOWLEDGEMENTS}

The author of this paper expresses his thanks to J.S. Sørensen, the crew of $R / V$ Pâmiut, and the staff (Greenland Institute of Natural Resources, Greenland) associated with annual surveys off Greenland, Mr. Kape and the $F / V$ Sisimiut for sampling in Greenland waters, H. Siegstad and N.H. Arboe (GINR) for logistics, R. Thiel (Zoological Museum Hamburg, Germany) for catch and specimen information, S. Ahyong, K. Graham, A. Hay, J. King, M. Lockett, M. McGrouther, and S. Reader (Australian Museum Sydney, Australia) for help with X-rays, photography and logistics, I. Byrkjedal, G. Langhelle (Natural History Collections Bergen, Norway) for shipping specimens and information, D.B. Garcia, R. Bañón, and A. de Carlos (Universidade de Vigo) for access to sequences and specimen information, K. Conway (University of Texas) for specimen examination, J. Pogonoski, A. Graham, B. Ward, and S. Appleyard (Commonwealth Scientific and Industrial Research Organisation, Australia), T. Sutton, A. Bernard, R. Eytan, M. Shivji (DEEPEND project*), and T. Elliott, R. Hanner and D. Steinke (Boldsystems.org) for access to sequences, A.M. Prokofiev (Severtsov Institute of Ecology and Evolution) for information, S.W. Knudsen for DNA samples and M.A. Krag (Zoological Museum University of Copenhagen, Denmark) for X-rays, catalogue numbers, and shipping the specimen. I owe a special thanks to J.R. Paxton (Australian Museum Sydney, Australia), G.A. Boxshall (British Museum of Natural History, U.K.), J. Hlidberg (private, www.fauna. is, Iceland), and T.W. Pietsch (Burke Museum University of Washington, U.S.) T.P. Satoh (The Kyoto University
Museum, Japan) for advice, barcodes, specimen examinations, or help with illustrations. I thank reviewers for constructive comments. This research received no specific grant from any funding agency, commercial or not-for-profit sectors (part of a larger effort to register the biodiversity and facilitate onboard fish identification in Greenland and subarctic Atlantic waters).

\section{REFERENCES}

Anonymous 2012. Free and open access to biodiversity data. GBIF; Global Biodiversity Information Facility. [Accessed on 1 March 2017.] https://www.gbif.org

Bañón R., Arronte J.C., Vázquez-Dorado S., Del Río J.L., De Carlos A. 2013. DNA barcoding of the genus Lepidion (Gadiformes: Moridae) with recognition of Lepidion eques as a junior synonym of Lepidion lepidion. Molecular Ecology Resources 13 (2): 189199. DOI: $10.1111 / 1755-0998.12045$

Bañón R., Barros-García D., Arronte J.C., Comesaña A.S., Sánchez-Ruiloba L., de Carlos A. 2019. Deep sea anglerfishes (Lophiiformes: Ceratioidei) from the western North Atlantic: Testing the efficacy of DNA barcodes. Journal of Zoological Systematics and Evolutionary Research 57 (3): 606-622. DOI: 10.1111/jzs.12281

Bañón R., Pietsch T.W., Piñeiro C.-G. 2006. New record of Linophryne coronata (Lophiiformes, Linophrynidae) from the North-eastern Atlantic Ocean. Cybium 30 (4): 385-386.

Barros-García D., Bañón R., Arronte J.C., FernándezPeralta L., García R., Iglésias S.P., Sellos D.Y., Barreiros J.P., Comesaña Á.S., De Carlos A. 2018. New insights into the systematics of North Atlantic Gaidropsarus (Gadiformes, Gadidae): Flagging synonymies and hidden diversity. Marine Biology Research 14(1): 17-29. DOI: 10.1080/17451000.2017.1367403

Bertelsen E. 1951. The ceratioid fishes. Ontogeny, taxonomy, distribution and biology. Dana Reports 39: $1-276$.

Bertelsen E. 1976. Records of parasitic males in three species of Linophryne (Pisces, Ceratoidea). Steenstrupia 4: 7-18.

Bertelsen E. 1986. Ceratioidei. Pp. 1371-1414. In: Whitehead P.J.P., Bauchot M.-L., Hureau J.-C., Nielsen J., Tortonese E. (eds.) Fishes of the North-eastern Atlantic and the Mediterranean. Vol. 3. UNESCO, Paris.

Bertelsen E., Krefft G. 1965. On a rare ceratioid fish, Linophryne lucifer Collett, 1886. Videnskabelige Meddelelser fra den Naturhistoriske forening i Kjøbenhavn 128: 293-301.

Boxshall G.A. 1998. Host specificity in copepod parasites of deep-sea fishes. Journal of Marine Systems 15 (14): 215-223. DOI: 10.1016/S0924-7963(97)00058-4

Chang C.-H., Shao K.-T., Lin H.-Y., Chiu Y.-C., Lee M.-Y., Liu S.-H., Lin P.-L. 2017. DNA barcodes of the 
native ray-finned fishes in Taiwan. Molecular Ecology Resources 17 (4): 796-805. DOI: 10.1111/17550998.12601

Espiñeira M., González-Lavín N., Vieites J.M., Santaclara F.J. 2008. Authentication of anglerfish species (Lophius spp) by means of polymerase chain reaction-restriction fragment length polymorphism (PCR-RFLP) and forensically informative nucleotide sequencing (FINS) methodologies. Journal of Agricultural and Food Chemistry 56 (22): 1059410599. DOI: $10.1021 /$ jf801728q

Gaemers P.A., Poulsen J.Y. 2017. Recognition and distribution of two North Atlantic Gadiculus species, $G$. argenteus and $G$. thori (Gadidae), based on otolith morphology, larval pigmentation, molecular evidence, morphometrics and meristics. Fishes 2 (3): e15. DOI: 10.3390/fishes2030015

Hansen K., Herring P.J. 1977. Dual bioluminescent systems in the anglerfish genus Linophryne (Pisces: Ceratioidea). Journal of Zoology 182 (1): 103-24. DOI: 10.1111/j.1469-7998.1977.tb04144.x

Haygood M.G., Distel D.L., Herring P.J. 1992. Polymerase chain reaction and $16 \mathrm{~S}$ rRNA gene sequences from the luminous bacterial symbionts of two deep-sea anglerfishes. Journal of the Marine Biological Association of the United Kingdom 72 (1): 149-159. DOI: 10.1017/S0025315400048852

Hendry T.A., Freed L.L., Fader D., Fenolio D., Sutton T.T., Lopez J.V. 2018. Ongoing transposon-mediated genome reduction in the luminous bacterial symbionts of deep-sea ceratioid anglerfishes. mBio 9 (3): e0103318. DOI: $10.1128 / \mathrm{mBio} .01033-18$

Jónsson G. 1967. Sjaldséður fiskur veiðist við Grænland. [A rare fish caught off Greenland.] Ægir 60 (17): 316317. [In Icelandic.]

Jónsson G., Pálsson J. 1999. Fishes of the suborder Ceratioidei (Pisces: Lophiiformes) in Icelandic and adjacent waters. Rit Fiskideildar 16: 197-207.

Jónsson G., Pálsson J. 2013. Islenskir Fiskar. [Icelandic fishes.] 2nd edn. Mál og menning, Reykjavík, Iceland. [In Icelandic.]

Kimura M. 1980. A simple method for estimating evolutionary rates of base substitutions through comparative studies of nucleotide sequences. Journal of Molecular Evolution 16 (2): 111-120. DOI: 10.1007/BF01731581

Klimpel S., Palm H.W., Busch M.W., Kellermanns E., Rückert S. 2006. Fish parasites in the Arctic deep-sea: Poor diversity in pelagic fish species vs. heavy parasite load in a demersal fish. Deep Sea Research Part I: Oceanographic Research Papers 53 (7): 1167-1181. DOI: 10.1016/j.dsr.2006.05.009

Klimpel S., Seehagen A., Palm H.W., Rosenthal H. 2001. Deep-water metazoan fish parasites of the world. Logos Verlag, Berlin, Germany.

Knebelsberger T., Landi M., Neumann H., Kloppmann M., Sell A.F., Campbell P.D., Laakmann S., Raupach M.J., Carvalho G.R., Costa F.O. 2014. A reliable DNA barcode reference library for the identification of the north European shelf fish fauna. Molecular Ecology Resources 14 (5): 1060-1071. DOI: $10.1111 / 1755-0998.12238$

Kenchington E.L., Baillie S.M., Kenchington T.J., Bentzen P. 2017. Barcoding Atlantic Canada's mesopelagic and upper bathypelagic marine fishes. PloS ONE 12 (9): e0185173. DOI: 10.1371/journal. pone. 0185173

Landi M., Dimech M., Arculeo M., Biondo G., Martins R., Carneiro M., Carvalho G.R., Brutto S.L., Costa F.O. 2014. DNA barcoding for species assignment: The case of Mediterranean marine fishes. PLoS One 9 (9): e106135. DOI: 10.1371/journal.pone.0106135

Lütken C. 1871. Oneirodes Eschrichtii Ltk. en ny grønlandsk Tudsefisk. [Oversigt over det Kongelige Danske Videnskabernes Selskabs Forhandlinger og dets Medlemmers Arbeider i Aaret 1871. Pp. 56-74. Oneirodes Eschrichtii noveau poisson du Grønland de la familie des Baudroies. Résumée du Bulletin de la Société Royale Danoise des Sciences pour l'année 1871. Pp. 9-18. [In Danish and French.]

Martin W.E. 1975. Hydrichthys pietschi, new species, (Coelenterata) parasitic on the fish, Ceratias holboelli. Bulletin of the Southern California Academy of Sciences 74 (1): 1-5.

McCusker M.R., Denti D., Guelpen L., Kenchington E., Bentzen P. 2013. Barcoding Atlantic Canada's commonly encountered marine fishes. Molecular Ecology Resources 13 (2): 177-188. DOI: 10.1111/1755-0998.12043

Miya M., Pietsch T.W., Orr J.W., Arnold R.J., Satoh T.P., Shedlock A.M., Ho H.-C., Shimazaki M., Yabe M., Nishida M. 2010. Evolutionary history of anglerfishes (Teleostei: Lophiiformes): a mitogenomic perspective. BMC Evolutionary Biology 10: e58. DOI: 10.1186/1471-2148-10-58

Miya M., Takeshima H., Endo H., Ishiguro N.B., Inoue J.G., Mukai T., Satoh T.P., Yamaguchi M., Kawaguchi A., Mabuchi K., Shirai S.M., Nishida M. 2003. Major patterns of higher teleostean phylogenies: A new perspective based on 100 complete mitochondrial DNA sequences. Molecular Phylogenetics and Evolution 26 (1): 121-38. DOI: 10.1016/S1055-7903(02)00332-9

Møller P.R., Nielsen J.G., Knudsen S.W., Poulsen J.Y., Sünksen K., Jørgensen O.A. 2010. A checklist of the fish fauna of Greenland waters. Zootaxa 2378 (1): $1-84$.

Munk O., Hansen K., Herring P.J. 1998. On the development and structure of the escal light organ of some melanocetid deep sea anglerfishes (Pisces: Ceratioidei). Journal of the Marine Biological Association of the United Kingdom 78 (4): 13211335. DOI: $10.1017 / \mathrm{S} 0025315400044520$

Parr A.E. 1927. Ceratioidae. Scientific results of the third oceanographic expedition of the "Pawnee" 1927. Bulletin of the Bingham Oceanographic Collection Yale University 3: 1-34. 
Piasecki W., Avenant-Oldewage A. 2008. Diseases caused by Crustacea. Pp. 1115-1200. In: Eiras J., Segner H., Wahli T., Kapoor B.G. (eds.) Fish diseases. Science Publishers, Enfield NH, USA.

Pietsch T.W. 1974. Osteology and relationships of ceratioid anglerfishes of the family Oneirodidae, with a review of the genus Oneirodes Lütken. Science Bulletin [Natural History Museum, Los Angeles County] No. 18: 1-113.

Pietsch T.W. 1976. Dimorphism, parasitism and sex: Reproductive strategies among deepsea ceratoid anglerfishes. Copeia 1976 (4): 781-793. DOI: $10.2307 / 1443462$

Pietsch T.W. 1978. A new genus and species of ceratoid anglerfish from the North Pacific Ocean with a review of the allied genera Ctenochirichthys, Chirophryne and Leptacanthichthys. Natural History Museum of Los Angeles County Contributions in Science No. 297: 1-25.

Pietsch T.W. 2002. Lophiiformes. Pp. 1043-1070. In: Carpenter K.E. (ed.) The living marine resources of the Western Central Atlantic. Volume 2: Bony fishes part 1 (Acipenseridae to Grammatidae). FAO Species Identification Guide for Fishery Purposes and American Society of Ichthyologists and Herpetologists Special Publication 5. Rome.

Pietsch T.W. 2005. Dimorphism, parasitism, and sex revisited: Modes of reproduction among deep-sea ceratioid anglerfishes (Teleostei: Lophiiformes). Ichthyological Research 52 (3): 207-236. DOI: 10.1007/s10228-005-0286-2

Pietsch T.W. 2009. Oceanic anglerfishes. Extraordinary diversity in the deep sea. University of California Press, Berkeley and Los Angeles, London.

Pietsch T.W., Orr J.W. 2007. Phylogenetic relationships of deep-sea anglerfishes of the suborder Ceratioidei (Teleostei: Lophiiformes) based on morphology. Copeia 2007 (1): 1-34.

Poulsen J.Y. 2015a. Fifth confirmed record and North Atlantic range expansion of the rare pelagic bobtail snipe eel genus Neocyema (Cyematidae, Elopomorpha). Marine Biodiversity Records 8: e53. DOI: $10.1017 / \mathrm{S} 175526721500024 \mathrm{X}$

Poulsen J.Y.2015b. A new species of pencil smelt Nansenia boreacrassicauda (Microstomatidae, Argentiniformes) from the North Atlantic Ocean. Zootaxa 4020 (3): $517-$ 532. DOI: 10.11646/zootaxa.4020.3.6

Poulsen J.Y., Byrkjedal I., Willassen E., Rees D., Takeshima H., Satoh T.P., Shinohara G., Nishida M., Miya M. 2013. Mitogenomic sequences and evidence from unique gene rearrangements corroborate evolutionary relationships of Myctophiformes (Neoteleostei). BMC Evolutionary Biology 13: e111. DOI: $10.1186 / 1471-2148-13-111$
Poulsen J.Y., Sado T., Hahn C., Byrkjedal I., Moku X., Miya M. 2016. Preservation obscures pelagic deep-sea fish diversity: Doubling the number of sole-bearing opisthoproctids and resurrection of the genus Monacoa (Opisthoproctidae, Argentiniformes). PLoS One 11 (8): e0159762. DOI: 10.1371/journal.pone.0159762

Poulsen J.Y., Thorkildsen S., Arboe N.H. 2018. Identification keys to halosaurs and notacanthids (Notacanthiformes, Elopomorpha) in the subarctic Atlantic Ocean including three new distributional records and multiple molecular OTUs of Notacanthus cf. chemnitzii. Marine Biodiversity 48 (2): 1009-1025. DOI: $10.1007 /$ s12526-017-0762-8

Prokofiev A.M. 2014. New species and new records of deepsea anglerfish of the family Oneirodidae. Journal of Ichthyology 54 (8): 602-607. DOI: 10.1134/ S0032945214050075

Ratnasingham S., Hebert P.D.N. 2007. BOLD: The Barcode of Life Data System (www.barcodinglife. org). Molecular Ecology Notes 7 (3): 355-364. DOI: 10.1111/j.1471-8286.2007.01678.x

Sutton T.T., Clark M.R., Dunn D.C., Halpin P.N., Rogers A.D., Guinotte J., Bograd S.J., Angel M.V., Perez J.A.A., Wishner K., Haedrich R.L., Lindsay D.J., Drazen J.C., Vereshchaka A., Piatkowski U., Morato T., Blachowiak-Samolyk K., Robison B.H., Gjerde K.M., Pierrot-Bults A., Bernal P., Reygondeau G., Heino M. 2017. A global biogeographic classification of the mesopelagic zone. Deep Sea Research Part I: Oceanographic Research Papers 126: 85-102. DOI: 10.1016/j.dsr.2017.05.006

Sutton T.T., Letessier T.B., Bardarson B. 2013. Midwater fishes collected in the vicinity of the SubPolar Front, Mid-North Atlantic Ocean, during ECOMAR pelagic sampling. Deep Sea Research Part II: Topical Studies in Oceanography 98 (Part B): 292300. DOI: 10.1016/j.dsr2.2013.08.001

Vecchione M., Falkenhaug T., Sutton T., Cook A., Gislason A., Hansen H.Ø., Heino M., Miller P.I., Piatkowski U., Porteiro F., Søiland H., Bergstad O.A. 2015. The effect of the North Atlantic Subpolar Front as a boundary in pelagic biogeography decreases with increasing depth and organism size. Progress in Oceanography 138 (Part A): 105-115. DOI: 10.1016/j. pocean.2015.08.006

Ward R.D., Hanner R., Hebert P.D. 2009. The campaign to DNA barcode all fishes, FISH-BOL. Journal of Fish Biology 74 (2): 329-356. DOI: 10.1111/j.10958649.2008.02080.x

Received: 17 January 2019

Accepted: 31 March 2019

Published electronically: 15 December 2019 